This is the version of the chapter accepted for publication in: Maltby, Sarah and O'Loughlin, Ben and Parry, Katy and Roselle, Laura, (eds.), Spaces of War, War of Spaces. London: Bloomsbury Academic, pp. 143-158. https://www.bloomsbury.com/us/spaces-of-war-war-of-spaces-9781501360305/

Accepted version downloaded from SOAS Research Online: http://eprints.soas.ac.uk/34189

\title{
Liminality; gendering and Syrian alternative media spaces
}

\section{Dina Matar and Kholoud Helmi}

\section{Introduction}

The 2011 Syrian uprising has generated considerable debate about alternative protest media spaces and oppositional news practices that have emerged in a rapidly changing media environment and a long-term violent conflict - a debate that has largely become entangled with broader concerns around theorizing the role of media in conflict. Many of these discussions have focused on the potential of alternative/radical/protest/counter-hegemonic media for citizen journalism (Wessels 2019), activism, voice, political participation, agency and empowerment, the production of counter-hegemonic narratives (Crilley 2017; Matar 2016) as well as their role in the emergence of radically different political subjectivities often discussed, in Middle Eastern contexts, as products of liberated political imaginaries or as digital cultures of contention (Zayani 2015). These debates have also informed some studies around Arab women's media work and activism and their foregrounding of gender questions in socio-political transformations, with some scholars, such as Radsch and Khamis (2013), arguing that Arab women's digital activism had helped young women achieve leadership and visibility in the media, along with challenging mainstream (state or official) media narratives in relation to women, while others, such as Al-Rawi (2014), suggesting that the Arab Spring had helped launch digital feminist movements in predominantly patriarchal societies. Khamis (2018: 2) goes further in noting that just by engaging in multiple forms of struggle, Arab women contest and redefine "gendered spaces, politically, legally, and socially", while Sreberny cautions that studies of women's digital activism need to be more nuanced and consider connections between gendered subjectivities and other social identities, as well as 
the relationship between women and the nation state which ultimately "hinge on broader issues of equality and power" (2018: 112). ${ }^{1}$

In Syria, alternative protest media that burst into the Syrian public sphere at the beginning of the uprising without doubt provided Syrian women, as well as the wider population, with what Cammaerts (2012) calls 'mediation opportunity structures' to represent themselves, tell their own stories, exert agency, discuss socially taboo subjects in public and insert gender politics and practices into the agenda of the popular revolution. In doing so, these women built on pre-uprising processes that had seen the establishment of women associations and committees and formal and informal networks to challenge gender stereotypes, strengthen women's status and seek to amend laws that discriminate against women (al-Aous 2013). Such informal networks included websites such as al-thawra (www.al-thawra-sy.com) and the Syrian Women Observatory (www.nesasy.org), which are examples of some of the first websites that have provided knowledge on gender identity, women's lived conditions, improvement of women's and children's rights as well as youth, people with special needs, prisoners, environment, health and legal advice to women who suffer from domestic violence or threats to their lives (al-Aous 2013).

Acknowledging the agential potential of alternative protest Syrian media platforms post-2011, ${ }^{2}$ this chapter moves out of discussions that focus on the role of these media for empowerment and agency or those that discuss the production of counter-hegemonic discourses. Instead, it uses the optic of liminality to address these platforms as essentially liminal spaces of war that provide new fields of possibilities for Syrian women (as well as other members of the society) to tell their own stories and experiences of the uprising, and to construct and imagine new political and social subjectivities. ${ }^{3}$ Liminality is a term that refers to events, processes, or individuals that are on the threshold of, or in the early stages of, new social processes, which anthropologist Victor Turner has theorized as stages of transition and 
in-between positions that liminal individuals occupy. For Turner, liminality is a position of social and structural ambiguity, or as "the Nay to all positive structural assertions, but as in some sense the source of them all, and, more than that, as a realm of pure possibility whence novel configurations of ideas and relations may arise" (Turner 1967: 97). In liminal conditions, such as uprisings, revolutions and war, subjects become removed from the "familiar space, the routine temporal order, or the structures of moral obligations and social ties... [and]... enter a liminal time/space ... [in which] the transgression of norms and conventions becomes possible" (Yang 2000: 25), social markers disappear and subjects, differentiated along gender, sexual, ethnic, religious or racial lines, can imagine themselves as equal. This is because in situations when order and norms are dissolved and/or contested, lived experiences shape political consciousness and meaning making. ${ }^{4}$ Focusing on the concept of liminality in relation to media work during times of transition, Zizzi Papacharissi (2015) suggests that liminality allows media workers (journalists, editors, media managers, etc.) to engage in processes of transition through collaborative news co-creation, that she proposes is in itself liminal particularly because this form of engagement relies on the temporary dismantling of news rituals so as to be able to collectively (re)produce new ones. As she argues (2015:32):

Liminality is a middle point in a dialogue about what is news, in a society. It is a transitional, but essential stage in finding one's own place in the story and doing so from a position that allows autonomy and potential for agency. ...[but $] \ldots$ in order for this dialogue to be rendered liminal, all previous hierarchy about what makes news must be abandoned, and therein lies the empowering potential of liminality....the very function of liminality is to abandon structure so as to permit activity that will result in the birthing of a new structure, and therein lie both potential empowerment and disempowerment. 
The concept of liminality is particularly relevant to addressing women's media work in liminal conditions, such as the uprising turned war by the Syrian regime against all its opponents and characterized by upheaval and a breakdown in social order. To illustrate the argument, the chapter uses the example of Enab Baladi, one of the most prominent Syrian alternative media platforms that emerged following the March 2011 uprising, and draws on a select number of interviews with some of its female founders/media workers, who were involved in its creation from the beginning. The chapter is divided into two main sections: the first section discusses Enab Baladi as a liminal space of war that provides new fields of possibilities for women media workers to overturn structure and insert gender into the revolutionary agenda. The second section discusses how the protracted liminal state in Syria, exacerbated by the longevity and complexity of the war, is both ambiguous and precarious, and as such, provides new fields of possibilities for regime and other counter-revolutionary forces to re-instate social norms, re-institutionalize structure, suppress dissent and seek to reintegrate liminal actors into pre-uprising social structures. The chapter concludes by suggesting that liminality can help us theorize the role of media and conflict in protracted conflicts without overtly emphasizing the potential of media in social and political conflicts and change, but to ground this potential in temporalities and socio-political contexts.

\section{Liminal spaces of war}

Enab Baladi, which means "the Grapes of My Country", is one of many alternative media spaces and websites initiated by Syrian women in the context of the Syrian 2011 uprising these include Souriatna, Oxygen newspaper, the Kibreet blog, the Dahnoon blog and Al Haq newspaper. While these media initiatives grew out of the Syrian uprising against oppression and economic deprivation that began in March 2011, they built on and extended a number of pre-uprising small and scattered initiatives that had also harnessed digital spaces to improve women's social status as well as draw attention to the conditions of women in predominantly 
patriarchal societies. Many of these initiatives used the Internet and social media platforms to disseminate their views and fight patriarchy - for example Musawa (equality), an independent civil society organization founded in 2009 by a group of Syrian women to fight gender-discrimination and enable effective participation of women in the political, social, economic and cultural spheres of Syrian society and the collective Syrian Women for the Syrian Intifada, a network of women initially aimed at supporting families of detainees and martyrs, which later broadened its activities to support grassroots' activists who had lost their jobs or of those who had gone into hiding for their political stances.

Enab Baladi started as a weekly printed newspaper distributed by hand with the aim of disseminating news and information of the popular uprising and to counter the regime's narrative which had dominated the media sector for more than 40 decades. The paper was founded by young Syrian female and male activists, including the co-author of this chapter Kholoud Helmi, in the Syrian town of Daraya, one of the main Syrian towns where popular protests for political and human rights began. Since its foundation, the newspaper has focused on publishing first-hand personal narratives of the uprising and of ordinary people's lived experiences, aspirations and needs as well as reports on women's involvement and participation in the uprising and in building collaborative protest networks bringing together opposition actors. During its foundation phase, various roles and responsibilities, such as interviewing, editing, assigning news stories and reporting from the battleground, were distributed in basic ways among the amateur founders, with some individuals taking on several reporting and editorial duties at the same time. Organization of tasks was simple and voluntary and questions of journalistic professionalism in news gathering and news telling were not pivotal particularly at a time when holding a camera was considered a state crime. Most activities and media work were underground, compared to later stages, where teams were more organized and structures more developed. By 2019, buffeted by support from the 
EU and by international recognition of its contribution, Enab Baladi had developed into one of the most important independent Syrian media institutions, published both in print in Turkey and shipped to northern parts of Syria where some opposition strongholds remain and online through its website and Facebook page which attract about two million page views a month. ${ }^{5}$

In its early stages, Enab Baladi's media workers were mainly composed of volunteers and citizen journalists, including women, who focused on telling the stories of ordinary lives in conflict and providing eyewitness accounts of unfolding events - tasks which one of its female co-founders, Afraa Sharbaji (2018), said in an interview were essentially concerned with providing facts and information of the unfolding events and "an alternative view to that of the regime's while paying particular attention to the Syrian people, their fears, struggles, dreams and aspirations". The fact that women were some of the main founders influenced the stories they chose to tell and had access to, particularly because Syrian women were willing to speak to the female journalists about sensitive topics, including rape by security forces and militias. But this fact also reflected, according to our informants, a deep change in popular perceptions towards women evident in the early days of the uprising. ${ }^{6}$ These perceptions, as Manal Shakashiro (2018), a Enab Baladi reporter and cofounder, said were "not only witnessed in women's media work, which brought them visibility, but also in other public roles women took on". For co-author of this chapter and cofounder of Enab Baladi, Kholoud Helmi, women, particularly those who had been marginalized before or who come from conservative and low-income backgrounds, were encouraged into taking new social and public roles, including media work, because of the transformative potential of the uprising as well as support from male colleagues and male family members, helping them gain recognition in their local communities as they established networks with other communities for social and political support. ${ }^{7}$ As she said: "Personally, I 
was empowered because (the revolution) showed me I could speak up and ask for my rights and the rights of others and allowed me to challenge gender norms institutionalized under a dictatorship" (Helmi 2018), underlining how these women occupied liminal positions as a stage of transition and in-between positions during times of upheaval.

During that stage ${ }^{8}$ and before the conflict became more violent, most of the informants said they did not feel they were different from men, particularly because they were all united by similar revolutionary goals, reflecting how liminal conditions also helped remove them from the "familiar space, the routine temporal order, or the structures of moral obligations and social ties..." and enter a liminal media space (Enab Baladi) in which transgression of norms and conventions became possible, social markers disappeared and subjects were imagined as equal. All the interviewees said that it was the revolutionary agenda that spurred their activism in ways that did not exist before - for example, they found themselves assuming influential, decision-making roles as activists, journalists, human rights defenders and advocates, and they became aware of other roles they could take outside their household, blurring the public/private divide. For Sharbaji, it was during this stage that her imagination of what it meant to be a Syrian woman contested the imagined Syrian woman imposed by the ruling Ba'ath Party's ideologies. As she put it, "I was able to know what it means to be a Syrian woman because I was able to have my voice heard and to freely participate in its political and social life" (Sharbaji 2018).

It is in this sense that Enab Baladi can be understood, as we propose, as a liminal space of war in which women media workers engaged in practices and imagined themselves as subjects from a liminal point of access (or an in-between position), and it is from that position that they were able to insert gender into the agenda of the uprising. For example, they discussed socially taboo subjects, such as sexual violence against women (a common practice even before the uprising) (see The Day After 2018); women's lives in conflict, not 
only as mothers, daughters or sisters, but as equal social actors with men; the regime's violations against women and Islamic State's brutal punishment of women who do not meet the strict Islamic dress code it imposed or those who appeared in public. Indeed, the mere coverage of such sensitive issues defined alternative media spaces as new spaces for antistructure and spaces in which social norms can be challenged, as evidenced in the stories and reports the newspaper covered since 2012 (for examples of these stories, see Enab Baladi (2019). Importantly, as we suggest that Enab Baladi as a liminal space of war provides new possibilities for making visible the ways in which Syrian women carry on everyday life activities without male members to support them, the ways women refugees take the lead in caring for families in refugee camps and displacement sites, the use of women as weapons of war, the increasing practices of taking women as slaves and the practice of forcing young female orphans into early marriage, topics that are normally considered taboo in maledominated society (Enab Baladi 2017).

\section{Patriarchy and ideology}

A deep understanding of how liminal spaces of war, such as Enab Baladi, provided new possibilities for Syrian women during conflict cannot be fully understood without discussing gender relations and ideologies and the social, political and economic context in Syria pre2011, which is beyond the scope of this chapter. Briefly however, in her co-edited book Women's Rights in the Middle East and North Africa: Progress Amid Resistance (2010), Sanja Kelly suggests that in Syria, "women had been treated as subordinate to men in the highly patriarchal culture, and social customs place gender-based restrictions on their rights" (Kelly 2010: 479). In Syria, men have traditionally dominated formal spaces, like politics, academics or religion, while most women have been more present in informal spaces, like the family, households and in social community work. Even in the relative normality of life 
before the war in Syria, women suffered from institutional discrimination, particularly in relation to questions of citizenship, custody of children (after divorce or separation), freedom of movement, and basic rights (Syrian women are not allowed to pass on their nationality to their children if married to non-Syrian men, whereas men have this right. Syrian woman cannot travel without their husband's approval, while men can. In addition, Syrian women of all ages are required to have male guardians to contract their marriages, while adult men are free to contract their own marriages).

Broadly speaking, institutionalized gender norms and imbalances in gender structures extended to the media work women undertook in various media institutions that had been regulated and controlled by the Ba'thist Syrian regime since it came to power in 1963 . These media institutions, such as the three main newspapers Tishreen, Al-Ba'ath, and Al-Thawra, along with the Syrian Arab News Agency, state radio, and television, did not allow much visibility or voice to women activists, restricting their attention to well-known women such as first lady Asma al-Assad or those who held official positions in the government, including membership of parliament. Indeed, despite the fact that Syrian women's political struggles and their vital participation in the anti-colonial independence movement had gained them the right to vote in 1949, a majority of women continued to have to make difficult choices about what roles to play within the (largely patriarchal) Syrian society controlled and regulated by the nationalist discourse of the ruling Ba'th Party as well as the regime's broader project of mass mobilization and modernization (Wedeen 1999; Matar 2019) which allowed it to maintain structural control of women's organizations (Meininghaus 2016). While on the face it, the project was committed to improving women's conditions and achieving the regime's promise of gender equality, it did not represent any ideological commitment to a profound change in the nature of gender relations in Syrian society or the elimination of legislative discrimination against women (Kelly and Breslin 2010), which, along with the exclusion of 
women from the Syrian nationalist narrative, has served to maintain power relations and bolster gendered hierarchies in the national imagination while fragmenting women's efforts to form independent women's movements.

Like other nation-states in the Arab world, women in Syria had often been used as symbols of the nation's development and modernization plans and represented in national discourse as the mothers, daughters or sisters of the Syrian Arab nation, thus concealing gender inequalities by attempting to justify them on the basis of family, religion, history, or other cultural terms. The symbolic connection between the idea of woman and the idea of nation and the use of women as symbols of nations by nationalist and liberationist movements has been critical to the gendering of women's membership in national communities (Joseph 2010). Sara Ruddick (1997: 213) suggests that the association of motherhood with nation and fatherhood with state is dangerous, bringing in "the worst of fatherhood: a right, often conjoined with real power, to intrude, humiliate, exploit, and assault". While the forms of patriarchy change, the linkage of woman/mother to nation and man/father to state reinforces the production of gendered hierarchy and facilitates the institutionalization of gendered citizenship in state-building projects. In the original discourses and policies of the Syrian Ba'th Party, women were constructed and imagined as 'national subjects' (own emphasis) who supposedly were allocated the same rights and duties as their male compatriots, a discourse that represented a specific form of 'state feminism' under the largely secularist discourse of the regime (see Sparre 2008). This form of state feminism constructed an image of the ideal Syrian woman as a modern, unveiled, educated and emancipated woman who performed citizenship and national duties as stipulated by the Ba'th Party rhetoric about who is a "good citizen" (Wedeen 2013) a discourse disseminated in the regime-controlled media and which depicted good women citizens as outgoing, free and modern that occupy social roles. As one of our informants, Noura al-Jizawi (2018) 
suggested, such a discourse extended to narratives of what it meant to be a successful woman as that woman who contributed to and worked within regime-sanctioned structures, such as the General Union of Syrian Women. Prominent examples of these women are Najah al-Attar who served as minister of culture, and was appointed Vice-President in 2006, an unprecedented move in the Arab World, and Buthaina Sha'aban, a member of the regime's political elites and political media adviser to the Syrian President Bashar al-Asad. In the official media — and the private media related to the regime - women were portrayed in three main ways: as wives and mothers; as modern, outgoing women who worked mainly in art and as hardworking women working in rural environments. After the Syrian uprising in March 2011, state media began to change some stereotypical images of Syrian women, representing them as having a key role in the regime's war against opponents - for example, successful and national Syrian women were discussed as those who send their sons to join the Syrian army to defend the country against what it called enemies. These discourses did not mean women were free to participate in independent women's movements nor that women concerns were discussed in the official state-run Syrian media.

\section{Liminal ambiguity}

It was not until the uprising that Syrian women felt empowered to challenge structural limitations and gendered discourses as part of broader processes calling for change and more political and social rights became possible, and it was during the early more peaceful stages of the popular protests that alternative protest media provided them with the spaces to contest norms and resist authoritarian power. As al-Jizawi said, Enab Baladi allowed her and other Syrian women to do things differently, move out of private places and thrust themselves into the public sphere. Another informant Manal Shakashiro went further to suggest that Enab Baladi was in itself similar to an "intifada" (uprising), providing a space for acts of transgression and anti-structure from which to engage in public acts of defiance against social 
norms and construct new ways of imagining what it means to be a Syrian woman. It is not surprising that revolutionary processes open new social and political spaces for women. Indeed, as Nadje al-Ali (2012: 28) writes,

If we speak of the Middle East, the most commonly cited examples are the Egyptian anti-colonial and independence movement at the turn of the twentieth century that gave rise to the Egyptian women's movement; the Algerian war of independence in the time of French colonialism; and the Palestinian struggle against Israeli occupation. Yet, history also teaches us that during political transitions, women are regularly marginalized and tend to lose many of the gains they might have acquired, or have been promised, at the height of a revolutionary struggle.... the issue is not only the lack or very limited representation of women in crucial transitional bodies, such as the constitutional review committee, but perhaps more significantly, we see women's rights being actively violated and women's and gender-based issues sidelined, occasionally even ridiculed, sometimes by women themselves.

Indeed, as the popular protests shifted towards a violent stage of militarization which witnessed extreme violence and destruction, an increased risk of kidnapping, forced displacement, rape, sexual violence, torture and even enslavement, women began to experience marginalization in different ways. For our informants, gendered differentiations began to re-impose themselves in the newsroom and organizational practices, practices which coincided with the re-emergence of traditional normative beliefs about gender and the role of women in society along with the discursive instrumentalization of gender by various actors as part of their ideological battles over power. ${ }^{9}$ In the newsroom, as some of our informants said, gendered differentiations manifested themselves in the allocation of tasks and positions, 
which saw a downgrading of women's roles from managers and decision-makers and the reimposition of binaries between the public and private.

The seven women we interviewed for this chapter were some of the early pioneers who participated in creating media outlets after the 2011 revolution and for a short period of time had leading roles and responsibilities in Enab Baladi and other alternative protest media platforms. For co-author and media activist Helmi, gendering differentiations reasserted themselves in different ways and diverse spaces:

Even when we took part in demonstrations, we began to hear voices calling on women not to participate in the demonstrations. In the media, we began to see men taking over leading roles, such as chief executive officers, editors in chief and managing editors. The change also happened on the ideological level when most of the media began to change the discourse ... for example, we saw men reporters writing more about military issues and hard news and rarely focused on ordinary people' stories and experiences.

Gendering practices also began to be felt in the field. For example, when seeking to interview ordinary people and members of the opposition, Helmi reported that one young man, affiliated to the oppositional Free Syrian Army asked for a male reporter to speak to rather than her. Another informant Manal Shakashiro said men did not take her seriously as a woman and some of those she interviewed requested that a man be sent to talk to them instead. For her, male colleagues took over leading positions in the newsroom because it was more socially acceptable for men to be in the same place operating together, while it was not socially acceptable for a woman to work alongside a man. With increasing violence, many of the female journalists and founders left for Turkey where they established an office in Istanbul in 2014 and connected with international organizations ready to give training and funding to media organizations in Syria. 
Five of the women we interviewed for this chapter come from relatively conservative backgrounds where women had traditionally been expected to remain at home, but all said they were fully supported by their families to engage in opposition acts against the regime at the beginning of the uprising. Three of those interviewed belong to families that opposed the regime before 2011 and several come from vulnerable socio-economic backgrounds, corresponding to the findings of a recent report on alternative media platforms in Syria which showed that on average a high proportion of Syrian women media workers came from vulnerable socio-economic backgrounds (SFJN 2016). Most of the informants spoke of the challenges they faced following the escalation of violence, which brought new security challenges to the female journalists and their families. With increasing militarization of the conflict and the involvement of extremist religious groups, freedom of expression was curtailed and women media workers, particularly those with leading media positions, faced the additional threat of risk to their reputation and lives. Mais Qat, 30, a journalist who cofounded Rozana Radio, said: "Being a woman who works with a lot of men during times of war, where violence and aggression are the dominating language in the street and work offices as well; it is a big challenge that I faced" (Qat 2018)

According to the report 'Women in Emerging Syrian Media: 2011-2016' (SFJN 2016), on average, $54 \%$ of the workforce of what it called Emerging Syrian media in radio outlets were women, and over a third of the ESM print workforce (35\%) are women. However, only $38 \%$ of the women working in the ESM print outlets under review hold senior positions and only $4 \%$ of senior ESM journalists are women. The survey shows that common perceptions of women media workers tended to reflect a lack of belief in women's capabilities, a conviction that women are followers of men, and the understanding that women can be utilized as a useful tool to raise sympathy when they are portrayed as victims. Relying on discourse analysis of text and image, the report noted that women were portrayed 
as active players in the public sphere; as non-existent or confined to the private sphere; as victims or as objects of beauty, incapable of political involvement. In line with this trend, women are portrayed in some instances as active and in need of solidarity and partnership, but in many others as themselves in need of protection, sympathy, advice and help. Most of our informants said that from 2012, they faced security challenges such as the fear of detention, being killed, or arresting family members. Later, militarization, masculinity and religious mindset limited the freedom of expression. Women also were faced with aggressiveness towards reputation and ridiculing any work related to gender concepts and gendering the Syrian media to force them stop their activism, especially when these women are in leading positions.

A number of authors have noted that media production, generally speaking, is not gender neutral (for example, Ross and Carter 2011) and that media work is characterized by a number of patterns of gender inequality that relate to informality, autonomy and flexibility (Gill 2002). In Syria the patterns of gender inequality were fundamentally exacerbated by the protracted liminal state in Syria, which opened new fields of possibilities for regime and other counter-revolutionary forces to instrumentalize gender as a tool of war while engaging in gender-based violence to deter women from joining the opposition forces. ${ }^{10}$ These practices were also reiterated in official discourses about women, such as in the speeches of Syrian president Bashar al-Assad's wife Asma al-Assad in which she repeated the old Ba'thist discourse about what it means to be a good nationalist Syrian woman during the war against opponents. For example, in a speech on Mother's Day on 21 March 2018, she said: "The Syrian heroines are those who defended Syria, postponed their dreams, left their families and put on military uniforms instead of wedding dresses....they carried the fun to defend the soil of their homeland" (al-Assad 2018). ${ }^{11}$ The instrumentalization of gender became a tool for several actors in the conflict, but most visibly in the regime's use of gender 
as part of its narrative of Syria being in a grips of a crisis provoked by outsiders and 'others' in order to render its violence against Syrian people more comprehensible and acceptable As Szekely (2019: 2), writing about gender ideologies in the Syrian conflict, suggests:

while gender ideology may not be the most important point of division in the conflict, it gives those involved an easy reference point to use in positioning themselves in relation to the other participants in the war, and to signal that position publicly. This is particularly useful in that such signalling represents a low-cost way of indicating an actor's position in what is often a complex web of ideological divisions and alliances.

\section{Conclusion}

The Syrian conflict is one of the most complex conflicts in contemporary history. ${ }^{12}$ The conflict, now in its eighth year, has been described as the most socially mediated war due to the excessive use by diverse actors of different media platforms to disseminate ideologies, political positionings and images of war and violence, and as the first networked conflict in contemporary history. Compared with other Arab uprisings and long-term conflicts in the Middle East, the conflict has featured spectacular forms of violence mediated through a wide range of digital and social media practices created by a variety of content by a host of political activists, witnesses, rebels, state agents, and soldiers, underlining how media are part of social and political processes and are fundamentally implicated in practices of war as well as the battle over ideologies, image, rhetoric, and politics.

Theorizing media and long-term conflicts such as Syria's remains an elusive task. This chapter does not make grand claims as it has limited itself to using the optic of liminality to discuss alternative protest media and gendering processes and, in doing so, their potential for the redefinition, but also reinforcement, of social norms and gender distinctions. Liminality, in this sense, allows scholars to address the risks and opportunities for individuals 
and organizations alike during liminal times when subjects are "neither "in" nor "out"' but are separated from familiar space, routine temporal order or hegemonic social structures. As such, liminality helps us understand lived experiences and actions and alert us to the potential and limitations of alternative media spaces during times of upheaval and constant transformation, such as the conflict in Syria. While much of the literature has focused on the agential role these spaces play, this chapter has suggested that liminality can affect the role alternative media spaces play because it is ambiguous and precarious and because it can both provide fields of possibilities for transgressive public acts in order to disrupt structure and social norms, including gender norms and practices, as well as fields of possibilities for the re-instatement of social norms and the re-institutionalization of structure by counterrevolutionary forces. The approach taken here does not negate the role alternative media spaces have played in the Syrian war or its understanding, nor does it downplay the incredible bravery and agency of various Syrian actors in their opposition to entrenched systems of power. Rather, it has served to show the precarious conditions women media workers face during conflict and protracted conditions of liminality. Further research needs to be carried out on ideologies of gender in the Syrian conflict, ${ }^{13}$ particularly because gender has received less attention that other cleavages in the conflict, and particularly because gender continues to hold a central place in the constellation of narratives defining the Syrian conflict ecosystem and for those involved in and experiencing the conflict.

\section{Bibliography}

Al-Ali, N. (2012), 'Gendering the Arab Spring', Middle East Journal of Culture and Communication, 5: 26-31.

Al-Aous, Y. (2013), Feminist websites and civil society experiences in Syrian voices in prerevolution Syria; civil society against all odds, The Hague: Hivos.

Al-Assad, A. (2018), 'Syrian heroine soldiers and their mothers honoured, Excerpts from Mrs. Al-Assad Statements', PresidentAssad.net, 21 March. Available online: 
http://www.presidentassad.net/index.php?option=com_content\&view=category\&layout=blog

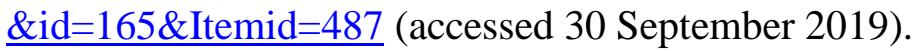

al-Jizawi, N. (2018), Interview by Kholoud Helmi, via Skype. 10 June 2018.

BBC News (2019), 'Why is there a war in Syria?', BBC News, 25 February. Available online: https://www.bbc.co.uk/news/world-middle-east-35806229 (accessed 10 October 2019).

Butler, J. (2004), Undoing Gender, London and NY: Routledge.

Cammaertz, B. (2012), 'Protest logics and the mediation opportunity structure', European Journal of Communication, 27(2): 117-134.

Cockburn, C. (2004). The Continuum of Violence, in: Wenona Giles and Jennifer Hyndman (eds.). Sites of Violence, Gender and Conflict Zones. Berkeley: University of California Press: $24-44$

Crenshaw, K. (1989) "Demarginalizing the Intersection of Race and Sex: A Black Feminist Critique of Antidiscrimination Doctrine, Feminist Theory and Antiracist Politics," University of Chicago Legal Forum: Vol. 1989, Article 8.

Crilley, R. (2017), 'Seeing Syria: The Visual politics of the National Coalition of Syrian Revolution and Opposition Forces on Facebook', Middle East Journal of Culture and Communication, 10 (2-3): 133-158.

Enab Baladi (2017), 'Syrian Women in the Vicious Circle of Violence', Enab Baladi, 9 December. Available online: https://english.enabbaladi.net/archives/2017/12/syrian-womenvicious-circle-violence/\#ixzz61wk3ry4q (accessed 10 October 2019).

Enab Baladi (2019), 'Citizen Chronicles of the Syrian Uprising', Enab Baladi. Available online: https://hummusforthought.com/wp-content/uploads/2019/05/enabbbaladi-book-web.pdf (accessed 10 October 2019). 
Gill, R. (2002), 'Cool, creative and egalitarian? Exploring gender in project-based new media work in Europe', Information, Communication \& Society, 5(1): 70-89.

Helmi, K. (2019). Interview with Dina Matar, 20 June 2019.

Issa, A. (2016), ‘Syria’s New Media Landscape', Middle East Institute, 6 December. Available online: https://www.mei.edu/publications/syrias-new-media-landscape (accessed 10 October 2019).

Joseph, S. (2010), 'Gender and Citizenship in the Arab World', al-Raida, 129-130: 8-19.

Kelly, S (2010). Hard-won progress and a long road ahead: Women's rights in the Middle Eat and North Africa in Kelly, S. and J. Breslin (2010), Women's rights in the Middle East and North Africa: Progress amid resistance. London: Freedom House, available online on https://freedomhouse.org/report/women039s-rights-middle-east-and-north-africa/womens$\underline{\text { rights-middle-east-and-north-africa-2010 }}$

Khamis, S. (2018), Arab Women's Activism and Socio-Political Transformation: Unfinished gendered revolutions. Cham, Switzerland: Palgrave MacMillan.

Matar, D. (2019), 'The Syrian regime's strategic communication: Politics and Ideology', The International Journal of Communication, 13: 2398-2416.

Matar, D. (2019), 'Narratives and the Syrian Uprising: the Role of Stories in Political Activism and Identity Struggles', in M. Zayani and S. Merghani (eds), Bullets and Bulletins, London: Hurst Co. and New York: Oxford University Press.

Meininghaus, E. (2016), Creating consent in Ba'thist Syria: Women and welfare in a totalitarian state. London: Bloomsbury.

O’ Brien, A. (2015), 'Producing Television and Reproducing Gender', Television and New Media, 16(3): 259-274.

Papacharissi, Z. (2015), 'Toward new Journalisms: Affective news, Hybridity and Liminal 
Spaces', Journalism Studies 16 (1): 27-40.

Qat, M. (2018) Interview by Kholoud Helmi, via Skype. 18 June 2018.

Radsch, C. and S. Khamis (2013), 'In their Own Voice: Technologically-mediated empowerment and transformation among young Arab women', Feminist Media Studies, 13(5): 881-890.

Ross, K. and Carter, C. (2011), 'Women and news: a long and winding road', Media Culture \& Society 33(8): 1148-1165.

SFJN (2016), 'Women in Emerging Syrian Media, 2011-2016', Stichting Female Journalists Network. Available online: http://www.sfjn.org/research-en.pdf (accessed 10 October 2019).

Shakashiro, M. (2018) Interview by Kholoud Helmi, via Skype. 25 June 2018.

Sharbaji, A. (2018) Interview by Kholoud Helmi, via Skype. 15 June 2018.

Sparre. S. (2008), 'Educated Women in Syria: Servants of the State, or Nurturers of the Family?', Critical Middle Eastern Studies, 17(1): 3-20.

Sreberny, A. (2018), 'Women's digital activism in a changing Middle East', in M. Zayani (ed.) Digital Middle East. London: Hurst.

Sweeney, B. (2009), ‘Producing liminal space: gender, age and class in Northern Ontario’s tree planting industry', Gender, Peace and Culture, 16(5): 569-586.

Szekely, O. (2019), 'Fighting about women: Ideologies of Gender in the Syrian Civil War', Journal of Global Security Studies. Avaiable online: https://doi.org/10.1093/jogss/ogz018 (accessed 10 October 2019).

The Day After (2018), 'Enab Baladi Video report On "Violence Against Women" Workshop In Idleb Countryside', The Day After. Available online: https://tdasy.org/en/content/229/617/tda-in-the-news/enab-baladi-video-report-on-violence-againstwomen-workshop-in-idleb-countryside (accessed 10 October 2019). 
Turner, V. (1967), The Forest of Symbols: Aspects of Ndembu Ritual. Ithaca, NY: Cornell UP.

Yang, G. (2000), 'The Liminal Effects of Social Movements: Red Guards and the

Transformation of Identity', Sociological Forum, 15(3): 379-406.

Wedeen, L. (1999), Ambiguities of Domination: Politics, Rhetoric and Symbols in Contemporary

Syria. Chicago: Chicago University Press.

Wedeen, L. (2013), 'Ideology and Humour in Dark Times: Notes from Syria', Critical

Inquiry, 39(4): 841-873.

Wessels, J. (2018), Documenting Syria, Film-making, video activism and revolution.

London: Bloomsbury.

Zayani, M. (2015), Networked Publics and Digital Contention, Oxford: Oxford

University Press.

\footnotetext{
${ }^{1}$ One of the key theoretical contributions of feminist theory is the concept of intersectionality which provides the language and framework for examining interconnections between social categories, such as gender, and systems and offers explanations of the ways in which diverse members of specific groups, such as women, might experience lived experiences and the work place differently, depending on their ethnicity, sexual orientation, class or other social markers. The term was coined by Kimberle Crenshaw (1989), in her work on the intersection of race and gender in relation to African Americans.

${ }^{2}$ Roughly 100 new Syrian media projects were established after March 2011, according to Syrian journalists working in them. There were as many as 298 newspapers being circulated in different parts of the country during various periods of the uprising, in addition to 17 staterun or regime-affiliated newspapers (see Issa 2016).

${ }^{3}$ There is no space here to discuss imposed subjectivities in detail, but crucially the regime's Ba'athist nationalist ideology constructed Syrian subjects as national Arab subjects and Syrian women invariably as women who served this ideology, (see, for example Wedeen (1999)).

${ }^{4}$ We follow Judith Butler (2004) in addressing norms as operating within social practices, and, as such, as providing implicit standards of normalization.

${ }^{5}$ Please see Enab Baladi's website for further details at www.ennabbaladi.net, or to view their story in English: https://enabbaladi.org/en/.

${ }^{6}$ Most of the newspaper's founders, including co-author Helmi, have fled Syria. Some of its journalists were arrested, some were released and one died under torture, according to Helmi. ${ }^{7}$ This is a phase during men acknowledged women's role in general and particularly in reference to women's role in mobilising non-violent movements and becoming citizens.
} 
${ }^{8}$ The stage lasted until mid-2013 when different actors joined the battle for control of the country. For details about the conflict and its consequences, see (BBC News 2019).

${ }^{9}$ We follow Butler (2004: 42) in her argument that gender does not refer to "what one "is" nor to what one "has," but as an apparatus by which the production and normalization of masculine and feminine take place along with the interstitial forms of hormonal, chromosomal, psychic, and performative that gender assumes."

${ }^{10}$ Gender violence in wartime is a complex phenomenon and is generally regarded as not only referring to social practices during 'war' as opposed to 'peace', but as happening on a continuum. For example, Cynthia Cockburn, in her study of the persistence of violence before, during and post-conflict, further suggests there is a shift in discourse, especially in media representations, prior to political violence or armed conflict and that this discourse can stoke the violence of national patriotism against a rival nation, point a finger at "the enemy within, or deepen the sense of ethnic belonging in opposition to some "other" from whom "we" are different and by whom our culture or our religion, our very existences, is threatened' (Cockburn: 2004)

${ }^{11}$ PresidentAssad.net, 21 March. Available online: http://www.presidentassad.net/index.php?option=com_content\&view=category\&layout=blog

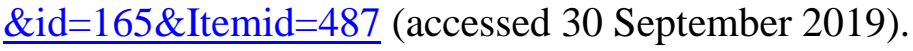

12 By the beginning of 2019, the Syrian conflict, had entered a phase marked by a broad consensus that the Assad regime had practically defeated its opponents, regained control of most opposition-held areas, and managed to sustain its long-standing mediated regime of representation.

${ }^{13}$ In the Syrian conflict, the Kurdish PYD and its armed wings have deployed an explicit inclusive position on women's rights and participation, attracting widespread international media coverage of Kurdish women fighters. The role of women fighters has consistently been a central part of the party's messaging in publicizing and promoting some military operations. Radical Islamist groups, such as Islamic State, also adopted ultra-conservative positions on women, issuing a memorandum on how Muslim women should do and act in the public and private space. As is the case for the PYD, IS's beliefs about gender constitute a central feature of its ideology. The organization adheres to and promotes a set of explicit, prescriptive beliefs about the roles of women and men in society and has used the enforcement of those laws as a means of signifying its authority in the areas it controls 